\title{
BACTERIAL CONTAMINATION AND PREVALENCE OF SOME FOODBORNE PATHOGENS IN EDIBLE BOVINE OFFAL IN ASSIUT CITY
}

\author{
ABD-EL-MALEK, A.M. and EL-KHATEIB, T. \\ Department of Food Hygiene (Meat Hygiene), Faculty of Veterinary Medicine, Assiut University, Assiut, Egypt
}

Received: 18 October 2016; Accepted: 21 November 2016

\begin{abstract}
This study was carried out to evaluate the bacterial contamination and prevalence of Salmonella spp. and Bacillus cereus in 150 samples of edible bovine by-products which were collected from different retail butcher's shops in Assiut city. The obtained results revealed that the mean values of total viable bacterial count (T.V.B.C.) of Tripe, Mombar (Intestine), Lung and Cerebrum (Brain) were $2 \times 10^{5} \pm 0.89,1 \times 10^{5} \pm 0.89,1 \times 10^{5} \pm 0.79$ and $8 \times 10^{4} \pm 1.06 \mathrm{CFU} / \mathrm{g}$, respectively. Wheras, it was indicated that 90 of the examined samples of edible offal (32 Tripe, 29 Mombar, 16 Lung and 13 Cerebrum) were more than $10^{3}$ (MPN/g) for total coliform count. Concerning Salmonella spp., 4 samples $(2.7 \%)$ only were positive for Salmonella spp. Isolated serovars were identified as $S$. Enteritidis, S. Typhimurium and S. Anatum. Regarding B. cereus, 12 samples (8\%) were positive, which included 5 samples of Tripe, 4 samples of Mombar and 3 samples of Cerebrum, while Lung samples were free. The average count of $B$. cereus in positive samples was $1.6 \times 10^{3} \mathrm{CFU} / \mathrm{g}$, where average number in Tripe, Mombar and Cerebrum were $3 \times 10^{3}, 1.4 \times 10^{3}$ and $5 \times 10^{2} \mathrm{CFU} / \mathrm{g}$, respectively. The achieved results indicated that consumption of edible bovine by-products such as Tripe, Mombar, Lung and Cerebrum constitute a public health hazard as they may be associated with food poisoning microorganisms such as $S$. Typhimurium and $S$. Enteritidis.
\end{abstract}

Key Words: Edible bovine by-products, bacteriological contamination, S. Typhimurium, S. Enteritidis, B. cereus.

\section{INTRODUCTION}

Edible bovine by-products (offal) have recently received significant attention worldwide (Im et al., 2016). In Egypt, edible bovine by-products such as Tripe, Mombar (Intestine), Lung and Cerebrum (Brain) are more popular, less expensive and have high nutritive value for consumers. They have a good nutritional value due to the high protein and low fat levels as well as good content in vitamins and minerals (Anderson, 1988). Nowadays, Salmonella is one of the most pathogenic genera implicated in food-borne bacterial outbreaks and diseases and that constitute an important public health problem. There are numerous transmission routes for Salmonellosis, but the majority of the human infections are derived from consumption of contaminated foods especially those of animal origin (Saha et al., 2016). Also, B. cereus was identified as a causative agent in $19 \%$ of foodborne outbreaks. The majority of these outbreaks were traced back to rice $(50 \%)$ and meat (24\%) (Bennet et al., 2013).

Numerous studies have described the numbers and types of bacteria on fresh meats. Whereas, studies

Corresponding author: Dr. ABD-EL-MALEK, A.M.

E-mail address: ashraf 702001@yahoo.com

Present address: Department of Food Hygiene (Meat Hygiene),

Faculty of Veterinary Medicine, Assiut University, Assiut, Egypt. evaluating the microbial contamination of diverse edible offal and specifically investigating contamination by pathogens that cause foodborne illnesses are rare. Moreover, there is scarce of the published information about the prevalence of Salmonella spp. and B. cereus in edible bovine byproducts obtained from retail butcher's shops in Assiut city. Such microbial contamination of edible bovine by-products may lead to public health problems. Therefore, the main objectives of this study were to enumerate total viable bacterial count, total coliform count and total Bacillus cereus count and determine the presence of Salmonella spp. and $B$. cereus on some edible bovine by-products commonly consumed in Assiut city, Egypt.

\section{MATERIALS AND METHODS}

\section{Samples collection:}

A total of 150 samples of edible bovine by-products including 40 samples of Tripe, 40 samples of Mombar (Intestine), 40 samples of Lung and 30 samples of Cerebrum (Brain) were collected from different butcher's shops in Assiut city. Each sample was obtained in separate sterile plastic bag. The collected samples were transferred directly to the laboratory where they were prepared for bacteriological examination. 


\section{Samples preparation:}

At the laboratory, each sample was aseptically and carefully freed from it's plastic bag and cut into fine particles by sterile scissor, then homogenized and thoroughly mixed. The fat and adhering extraneous materials on the surface of tripe were removed by knife and it was cut into small chunks of about $2.5 \mathrm{~cm}$ (Anna Anandh, 2004).

\section{Bacteriological analysis:}

3.1- Total viable bacterial count: (ISO protocol, 2003).

3.2- Total coliform count: (ISO protocol, 2006).

3.3- Count and isolation of B. cereus: (BAM, 2012). 3.4- Isolation of Salmonella spp: Identification of presumptive colonies by biochemical reactions (ISO protocol, 2002). Serological identification of Salmonellae was carried out according to Kauffman White scheme (Kauffman, 1974) for the determination of Somatic $(\mathrm{O})$ and Flagellar $(\mathrm{H})$ antigens using Salmonella antisera (Denka Seiken Co., Japan).

\section{RESULTS}

Table 1: Statistical values of total viable bacterial count (CFU/g) of examined samples of edible bovine byproducts.

\begin{tabular}{lcllll}
\hline & & \multicolumn{3}{c}{ Total viable bacterial count (cfu/g) } \\
\hline Samples & No. of samples & Min. & Max. & Mean & \pm SD \\
\hline Tripe & 40 & $1 \times 10^{4}$ & $2 \times 10^{7}$ & $2 \times 10^{5^{*}}$ & \pm 0.89 \\
\hline Mombar & 40 & $6 \times 10^{3}$ & $3 \times 10^{7}$ & $1 \times 10^{5^{*}}$ & \pm 0.89 \\
\hline Lung & 40 & $3 \times 10^{3}$ & $9 \times 10^{6}$ & $1 \times 10^{5 *}$ & \pm 0.79 \\
\hline Cerebrum & 30 & $1 \times 10^{3}$ & $1 \times 10^{7}$ & $8 \times 10^{4 *}$ & \pm 1.06 \\
\hline
\end{tabular}

*Lower than Egyptian standards contamination load (ES, 2005).

Table 2: Statistical values of total coliform count (MPN/g) of examined samples of edible bovine by-products.

\begin{tabular}{lccccc}
\hline Samples & \multicolumn{4}{c}{ Coliform count (MPN/g) } \\
\cline { 2 - 6 } & No. & $<\mathbf{3}$ & $\mathbf{3} \leq \mathbf{1 0}$ & $\mathbf{1 0 \leq 1 0}^{\mathbf{2}}$ & $\mathbf{1 0}^{\mathbf{3}}$ \\
\hline Tripe & 40 & 0 & 2 & 6 & $32^{*}$ \\
\hline Mombar & 40 & 2 & 1 & 8 & $29^{*}$ \\
\hline Lung & 40 & 0 & 8 & 16 & $16^{*}$ \\
\hline Cerebrum & 30 & 1 & 4 & 12 & $13^{*}$ \\
\hline Total & $\mathbf{1 5 0}$ & $\mathbf{3}$ & $\mathbf{1 5}$ & $\mathbf{4 2}$ & $\mathbf{9 0}$ \\
\hline
\end{tabular}

*Higher than Egyptian standards contamination load (ES, 2005).

Table 3: Incidence of Salmonella spp. in examined samples of edible bovine by-products.

\begin{tabular}{|c|c|c|c|c|c|c|c|c|c|}
\hline \multirow{2}{*}{ Samples } & \multirow{2}{*}{$\begin{array}{l}\text { No. of examined } \\
\text { samples }\end{array}$} & \multicolumn{2}{|c|}{ Salmonella spp. } & \multicolumn{2}{|c|}{$S$. Enteritidis } & \multicolumn{2}{|c|}{ S. Typhimurium } & \multicolumn{2}{|c|}{ S. Anatum } \\
\hline & & No. & $\%$ & No. & $\%$ & No. & $\%$ & No. & $\%$ \\
\hline Tripe & 40 & 0 & 0 & 0 & 0 & 0 & 0 & 0 & 0 \\
\hline Mombar & 40 & 1 & 2.5 & 0 & 0 & 0 & 0 & 1 & 2.5 \\
\hline Lung & 40 & 3 & 7.5 & 2 & 5 & 1 & 2.5 & 0 & 0 \\
\hline Cerebrum & 30 & 0 & 0 & 0 & 0 & 0 & 0 & 0 & 0 \\
\hline Total & 150 & 4 & 2.7 & 2 & 1.33 & 1 & 0.67 & 1 & 0.67 \\
\hline
\end{tabular}

Table 4: Incidence and mean values of positive B. cereus from examined samples of edible bovine by-products.

\begin{tabular}{lcccc}
\hline Samples & No. of samples & $+v e$ B. cereus & \% of +ve B. cereus & $\begin{array}{c}\text { Mean } \\
(\text { CFU/g) }\end{array}$ \\
\hline Tripe & 40 & 5 & 12.5 & $3 \times 10^{3}$ \\
\hline Mombar & 40 & 4 & 10 & $1.4 \times 10^{3}$ \\
\hline Lung & 40 & 0 & 0 & 0 \\
\hline Cerebrum & 30 & 3 & 10 & $5 \times 10^{2}$ \\
\hline Total & $\mathbf{1 5 0}$ & $\mathbf{1 2}$ & $\mathbf{8}$ & $\mathbf{1 . 6}^{\mathbf{3}}$ \\
\hline
\end{tabular}




\section{DISCUSSION}

The obtained results in Table (1) indicated that the mean values of T.V.B.C. of total 150 examined samples of edible bovine by-products was ranged from $2 \times 10^{5}$ to $8 \times 10^{4} \mathrm{CFU} / \mathrm{g}$ which were lower than standards contamination load set by Egyptian Standards (ES, 2005). Meanwhile, other investigators such as Isabel-Legarreta (2011) recorded lower results. In addition, the finding in Table (1) indicated that the mean number of T.V.B.C. of examined samples of Mombar was $1 \times 10^{5} \mathrm{CFU} / \mathrm{g}$, lower results were reported by Mboto et al. (2012) who found that the bacterial count of Mombar samples was $1 \times 10^{3}$ CFU/g. The results also showed that mean values of T.B.C. of examined samples of Mombar was $1 \times 10^{5}$, of lung was $10^{5}$ and of Cerebrum was $8 \times 10^{4} \mathrm{log}$ CFU/g, Ahmed and Sarangi (2013) obtained nearly similar results as our findings.

According to the safe permissible limit stipulated by Egyptian Standards limits (ES, 2005) for total coliform count in edible offal (not exceed $10^{2}$ CFU/gm), it was indicated that 90 of the examined samples of edible offal (32 Tripe, 29 Mombar, 16 Lung and 13 Cerebrum) were accordingly unaccepted (Table 2). These obtained results were in agreement with other studies as Selvan et al. (2007) who recorded higher results of coliform count $\left(1 \times 10^{5}\right.$ $\mathrm{CFU} / \mathrm{g})$.

From the achieved results illustrated in Table (3), it could be concluded that 4 samples were positive for Salmonella spp. with overall percentage of $2.7 \%$. Three samples of lung contaminated with Salmonella (two samples were classified as $S$. Enteritidis and one sample was identified as $S$. Typhimurium). Moreover, one sample was categorized as S. Anatum in Mombar. These results might be occurred due to faulty rupture of gastrointestinal tract during slaughtering process which regarded as one of the most important sources of carcass and organ contamination with Salmonella at abattoirs (Stopforth et al., 2006).

The results demonstrated in Table (3) revealed that the Salmonella spp. failed to be isolated from Tripe and Cerebrum samples, this finding was disagree with the results recorded by Akkaya et al. (2012), who found Salmonella in these organs. On the other hand, higher overall Salmonella prevalence $(7.1 \%)$ in cattle offal were reported by Im et al. (2016).

The obtained data outlined in Table (4) showed that there were 12 samples were positive for B. cereus (5 tripe, 4 Mombar and 3 Cerebrum samples) and these numbers represent $8 \%$ of total number of samples. The mean number of $B$. cereus in Tripe samples was $3 \times 10^{3} \mathrm{CFU} / \mathrm{g}$ and Mombar samples was $1.4 \times 10^{3}$ $\mathrm{CFU} / \mathrm{g}$ while in Cerebrum samples was $5 \times 10^{2} \mathrm{CFU} / \mathrm{g}$.
From Table (4) it was obvious that the mean number of overall count of $B$. cereus in this study was $1.6 \times 10^{3}$ $\mathrm{CFU} / \mathrm{g}$. This value were below the pathogenic number of B. cereus which estimated as $10^{4} \mathrm{CFU} / \mathrm{g}$ (Lee et al., 2006). This obtained result was disagree with a related study conducted by Iroha et al. (2011), who found lower incidence of $B$. cereus (2\%) from 100 samples of beef meat included lung and Cerebrum samples and other internal organs.

\section{CONCLUSION AND RECOMMENDATIONS}

The achieved results in the present study indicated that total coliform count of the edible bovine offal samples were higher than the permissible limits and the most common Salmonella serotypes isolated were $S$. Enteritidis and $S$. Typhimurium so the presence of such food poisoning microorganisms may pose potential risk for public health. It is recommended that hygiene improvements are needed in the establishments selling edible bovine by-products to protect public health.

\section{REFERENCES}

Ahmed, S.A. and Sarangi, S.K. (2013): Analysis of bacterial contamination in fresh and finished meat products and their molecular identification. International Journal of Pharmaceutical Science Invention, 2, 7: 27-32.

Akkaya, L.; Ataby, H.I.; Gok, V. and Yaman, H. (2012): Prevalence of Salmonella in edible offal in Afyonkarashisar Province, Turkey. Kafkas Univ. Vet. Fak. Derg. 18, 4: 613-616.

Anna Anandh, M.; Lakshmanan, V.; Anjaneyulu, A.S.R. and Mendiratta, S.K. (2004): Effect of chemical treatment on deodorization and quality of buffalo rumen meat. Meat Sci., 2: 25-29.

Anderson, B.A. (1988): Composition and nutritional value of edible meat by-products. In: Pearson, A. M. and Dutson, T. R. (ed.). Edible meat byproducts. London and New York: Elsevier Applied Science, pp. 15-45.

BAM "Bacteriological Analytical Manual" (2012): Chapter 14: Bacillus cereus. Tallent, S. M.; Rhodehamel, E.J.; Harmon, S.M. and Bennett, R.W. January 2001; updated February 2012. U. S. FDA, Center for Food Safety and applied nutrition, College Park, MD.

Bennet, S.D.; Walsh, K.A. and Gould, L.H. (2013): Foodborne disease outbreaks caused by Bacillus cereus, Clostridium perfringens, and Staphylococcus aureus-United States, 1998-2008. Clin. Infect. Dis., 57, 3: 425-433. doi: $10.1093 / \mathrm{cid} / \mathrm{cit} 244$.

ES (Egyptian Standards) (2005): frozen kidneys, hearts, spleen, cerebrum (Cerebrum), pancreas and tongue. Egyptian Organization for standrdization and control, 2062-2005. 
Im, M.C.; Seo, K.W.; Bae, D.H. and Lee, Y.J. (2016): Bacterial quality and prevalence of foodborne pathogens in edible offal from slaughterhouses in Korea. J Food Prot., 79: 163-8.

Iroha, I.R.; Ugbo, E.C.; Ilang, D.C.; Oji, A.E. and Ayogu, T.E. (2011): Bacteria contamination of raw meat sold in Abakaliki, Ebonyi State Nigeria. J. Public Health Epidemiol., 3, 2: 4953.

Isabel-Legarreta, G. (2011): Spoilage Detection. In Handbook of Analysis of Edible Animal ByProducts, ch. 12, pp. 213.

ISO "International Organization for Standardization" 6579 (2002): (E) $4^{\text {th }}$ Ed. Microbiology- General Guidance on Methods for the detection of Salmonella, International Organization for Standardization, Geneve, Switzerland.

ISO "International Organization for Standardization” 4831 (2006): Microbiology of food and animal feeding stuffs - Horizontal method for the detection and enumeration of coliform - Most probable number technique. Geneva, ISO.

ISO "International Organization for Standardization” 4833 (2003): Microbiology of food and animal feeding stuffs. Horizontal method for the enumeration of microorganisms. Colony count technique at $30^{\circ} \mathrm{C}$.
Kauffman, G. (1974): Kauffmann white scheme. J. Acta. Path. Microbiol. Sci. 61: 385.

Lee, S.; Chung, H.; Shin, J.; Dougherrty, R.H. and Kang, D. (2006): Survival and growth of foodborne pathogens during cooking and storage of oriental rice cakes. J. Food Prot., 69: 3037-3042.

Mboto, C.I.; Agbo, B.E.; Ikpoh, I.S.; Agbor, R.B.; Udoh, D.I.; Ambo, E.E. and Ekim, M.A. (2012): Bacteriological study of raw meat of Calabar Abattoir with public health and veterinary importance. J. Microbiol. Biotech. Res., 2, 4: 529-532.

Saha, M.; Debnath, C.; Biswas, M.K.; Pramanik, A.K. and Murmu, D. (2016): Studies on the prevalence of Salmonella spp. in meat shop premises intended to sale meat for human consumption in North Kolkata, India. Int.J. Curr. Microbiol. App. Sci., 5, 4: 297-302.

Selvan, P.; Mendiratta, S.K.; Porteen, $K$. and Bhilegaonkar, K.N. (2007): Effects of lactic acid on quality of Buffalo offals. Internet Journal of Food Safety, 9: 29-36.

Stopforth, J.D.; Lopes, M.; Shultz, J.E.; Miksch, R.R. and Samadpour, M. (2006): Location of bung bagging during beef slaughter influences the potential for spreading pathogen contamination on beef carcasses. J. Food Prot., 69: 1452-1455.

\section{التلوث البكتيرى وانتشار بعض البكتيريا الممرضة في أحشاء الأبقار الصالحة للأكل في مدينة أسيوط \\ أشسرف محمد عبل المالك ، طلعبت الخطبب \\ E-mail: ashraf_702001@yahoo.com Assiut University web-site: www.aun.edu.eg}

أجريت هذه الدراسة على عدد ،10 عينة من أحشاء الأبقار الصالحة للأكل، حيث اشتملت على ،ـ عينة من كلا من المعدة

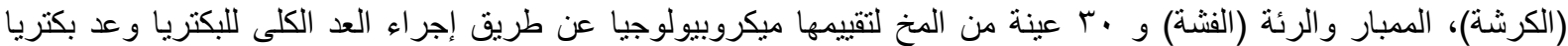

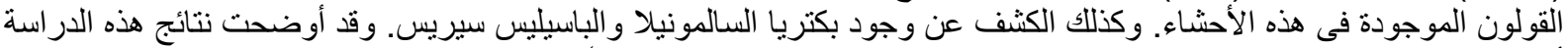

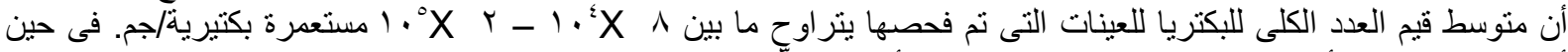

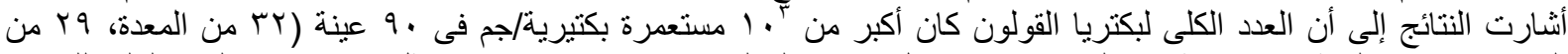

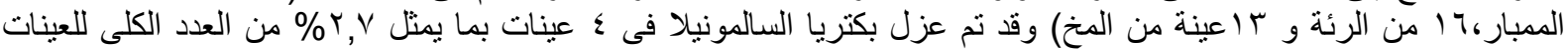

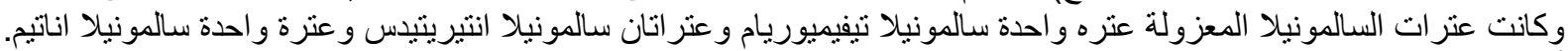

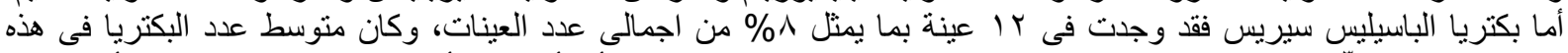

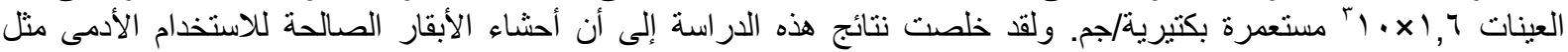

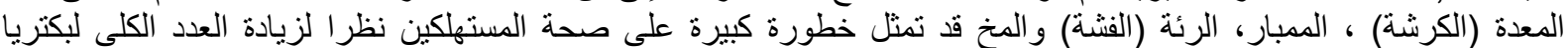
القولون بها وأيضا لوجود البكتريا المسبية للتسمم الغذائي مثل السالمونيلا تيفيميوريام و السالمونيلا انتيريتيدس. 